\title{
Cloning of a Novel vpr Gene Encoding a Minor Fibrinolytic Enzyme from Bacillus subtilis SJ4 and the Properties of Vpr
}

\author{
Zhuang Yao', Yu Meng', Huong Giang Le', Se Jin Lee', Hye Sung Jeon', Ji Yeon Yoo', \\ Hyun-Jin Kim ${ }^{1,2}$, and Jeong Hwan Kim ${ }^{1,2 *}$ \\ 'Division of Applied Life Science (BK21 Four), Graduate School, Gyeongsang National University, Jinju 52828, \\ Republic of Korea \\ ${ }^{2}$ Institute of Agriculture and Life Science, Gyeongsang National University, Jinju 52828, Republic of Korea
}

\begin{abstract}
We have previously characterized AprESJ4, the major fibrinolytic enzyme from Bacillus subtilis SJ4 (Yao et al., 2019). During that study, we observed a $68 \mathrm{kDa}$ protein with fibrinolytic activity. In this study, we cloned the gene (vprSJ4) encoding the $68 \mathrm{kDa}$ protein, a mature Vpr and minor protease secreted by Bacillus species. vprSJ4 encodes a preproenzyme consisting of 810 amino acids (aa) including signal sequence ( $28 \mathrm{aa}$ ) and prosequence (132 aa). The mature enzyme (650 aa) has a predicted molecular weight of $68,467.35$. Unlike Vprs from other B. subtilis strains, VprSJ4 has 4 additional amino acids (DEFA) at the C-terminus. vprSJ4 was overexpressed in Escherichia coli. PreproVprSJ4 was localized in inclusion bodies, and subjected to in vitro renaturation and purification by an affinity column. SDS-PAGE and western blot showed that autoprocessing of preproVprSJ4 occurred and $68 \mathrm{kDa}$ and smaller proteins were produced. The optimum $\mathrm{pH}$ and temperature of the recombinant $\mathrm{VprSJ} 4$ were $\mathrm{pH} 7.0$ and $40^{\circ} \mathrm{C}$, respectively. Kinetic parameters of recombinant VprSJ4 were measured by using an artificial substrate, $\mathbf{N}$-succinyl-ala-ala-pro-phe-pnitroanilide. Coexpression of vprSJ4 and aprESJ4 using pHY300PLK increased the fibrinolytic activity a further $117 \%$ when compared with aprESJ4 single expression using the same vector in B. subtilis WB600.
\end{abstract}

Keywords: vpr, aprE, fibrinolytic activity, Bacillus subtilis

Received: June 10, 2020 Accepted: August 8, 2020

First published online: August 21, 2020

*Corresponding author Phone: +82-55-772-1904 Fax: +82-55-772-1909 E-mail: jeonghkm@gnu.ac.kr

Supplementary data for this paper are available on-line only at http://jmb.or.kr.

pISSN 1017-7825 elSSN 1738-8872

Copyright(C) 2020 by The Korean Society for Microbiology and Biotechnology

\section{Introduction}

Bacillus species secrete several different proteases into culture medium at the end of log growth stage. Alkaline protease (Apr) and neutral protease (Npr) are the most important and major enzymes [1]. Other minor proteases include bacillopeptidase F, metallopeptidase, Vpr, Epr, and WprA [2]. Secreted proteases synthesized at the end of exponential growth phase help the host cells adapt to changed environments where nutrients, especially nitrogen sources, are limited [3]. However, the exact roles of each protease are still largely unknown. Some proteases possess strong fibrinolytic activities, and nattokinase, belonging to subtilisins (alkaline proteases), is the most well known example [4]. Bacillopeptidase $\mathrm{F}$ is another example and is also currently utilized as a thrombolytic agent together with nattokinase [5]. Nattokinase and bacillopeptidase F have been subjects of intensive study during last decades because they are considered promising alternatives for the medically important thromolytic agents such as t-PA (tissue plasminogen activator), urokinase, and streptokinase. Although these agents have been used to treat cardiovascular diseases caused by fibrin accumulation in the blood vessels, they have several shortcomings such as high cost, short in vivo half-lives, and internal bleeding [6]. B. subtilis and closely related Bacillus species are promising producers of more safe and economical fibrinolytic agents since they are considered as GRAS (generally recognized as safe).

In addition to providing peptides and amino acids for growth, proteases are responsible for other important functions. Subtilisin (AprE), Epr, and Vpr were shown to produce CSF (competence and sporulation factor), an extracellular signaling peptide, from its precursor [7]. AprE, WprA, and Vpr are responsible for the maturation of subtilin, a peptide antibiotic produced by B. subtilis [8]. More studies are necessary to discover the role of each protease on the growth of host cell during stationary phase.

Fermented foods are good sources for Bacillus sp. with strong fibrinolytic activities. A number of Bacillus sp. have been isolated from popular, traditional Korean fermented foods such as cheonggukjang, doenjang, jeotgal, and kimchi [9-12], and their AprE (subtilisin)-type proteases have been characterized most often. In this work, we cloned a $v p r$ gene ( $v$ prSJ4) from B. subtilis SJ4, an isolate from saeu jeotgal (small salted shrimp), followed by fermentation at room temperature for several months [12]. The gene product, VprSJ4, showed fibrinolytic activity. 
vprSJ4 was overexpressed in E. coli, the recombinant enzyme was purified, and the properties were studied. vprSJ4 was also coexpressed with aprESJ4 in B. subtilis WB600. The results will help us better understand the fibrinolytic system of $B$. subtilis SJ4 and find ways to use the strain in production of fermented foods or bioactive materials.

\section{Materials and Methods \\ Bacterial Strains and Culture Conditions}

B. subtilis SJ 4 and Escherichia coli strains were grown in Luria-Bertani broth (LB, tryptone $10 \mathrm{~g}$, yeast extract $5 \mathrm{~g}$, $\mathrm{NaCl} 5 \mathrm{~g}$, per liter, $\mathrm{pH} 7.0$ ) at $37^{\circ} \mathrm{C}$ with aeration. Chromosomal DNA of B. subtilis SJ4 was prepared from culture grown overnight in LB. Culture was centrifuged $\left(12,000 \times g, 5 \mathrm{~min}\right.$ at $\left.4^{\circ} \mathrm{C}\right)$, and cells were resuspended in $1 \mathrm{ml}$ of lysis buffer $(10 \mathrm{mM}$ Tris- $\mathrm{HCl}, 10 \mathrm{mM}$ EDTA, $100 \mathrm{mM} \mathrm{NaCl}, 2 \% \mathrm{SDS}$, and $400 \mu \mathrm{g} / \mathrm{ml}$ proteinase $\mathrm{K}$ (Takara, Japan, $\mathrm{pH}$ 8.0). After $30 \mathrm{~min}$ of incubation at $55^{\circ} \mathrm{C}$, phenol and chloroform extraction was done followed by isopropanol precipitation [13].

\section{SDS-PAGE and Fibrin Zymography}

B. subtilis SJ4 was grown in LB for $96 \mathrm{~h}$, and the culture supernatant was prepared at $12 \mathrm{~h}$ intervals. Proteins were concentrated by trichloroacetic acid (TCA) precipitation. A $10 \%$ acrylamide gel (5\% stacking gel) was used and $10 \mu \mathrm{g}$ sample was loaded after being boiled for $3 \mathrm{~min}$ in SDS sample buffer. Fibrin zymography was done using a $10 \%$ gel containing fibrin, which was prepared by mixing fibrinogen $(0.12 \%, \mathrm{w} / \mathrm{v})$ and $100 \mu \mathrm{l}$ of thrombin $(10 \mathrm{NIH}$ units $/ \mathrm{ml}$ ) with acrylamide solution. Culture supernatant ( $1 \mu \mathrm{g}$ protein) was directly loaded without TCA precipitation, and electrophoresis was done at $10 \mathrm{~mA}$ in a cold room. After electrophoresis, the fibrin gel was soaked in $50 \mathrm{mM}$ Tris-HCl buffer ( $\mathrm{pH} 7.4$ ) containing $2.5 \%$ Triton X-100 for $30 \mathrm{~min}$ at room temperature (RT) on a rotary shaker. The gel was washed with distilled water for $30 \mathrm{~min}$ to remove Triton X-100 and soaked in zymogram reaction buffer $\left(30 \mathrm{mM}\right.$ Tris- $\mathrm{HCl}, \mathrm{pH} 7.4$, and $\left.0.02 \% \mathrm{NaN}_{3}\right)$ for $12 \mathrm{~h}$ at $37^{\circ} \mathrm{C}$. The gel was stained with Coomassie Blue R-250 for $1 \mathrm{~h}$, and destained for $4 \mathrm{~h}[14]$.

\section{Cloning of $v$ prSJ4}

A primer pair was designed based on the published $v$ pr gene sequence, vprSJ4F (5'-CGCGGATCCTTGAAA AAGGGGATCATTCGCTTTC-3', BamHI site underlined) and vprSJ4R (5'-ACGCGAATTCGTCTTCAACAG TGAA AGGTTCTTCGGAC-3', EcoRI site underlined) [15]. PCR was done using an MJ Mini Personal Thermal Cycler (BioRad, USA). The reaction mixture $(50 \mu \mathrm{l})$ contained $1 \mu \mathrm{l}$ of template DNA, $1 \mu \mathrm{l}$ of each primer $(10 \mu \mathrm{M})$, $1 \mu \mathrm{l}$ of deoxynucleoside triphosphates $(0.25 \mathrm{mM})$, and $0.5 \mu \mathrm{l}$ of Ex Taq DNA polymerase (Takara). The amplification conditions were as follows: initial denaturation at $94^{\circ} \mathrm{C}$ for $5 \mathrm{~min}, 30$ cycles of $94^{\circ} \mathrm{C}$ for $0.5 \mathrm{~min}, 69^{\circ} \mathrm{C}$ for $0.5 \mathrm{~min}$, and $72^{\circ} \mathrm{C}$ for $2 \mathrm{~min}$, and final extension at $72^{\circ} \mathrm{C}$ for $4 \mathrm{~min}$. Amplified fragment was ligated with pGEMT Easy Vector (Promega, USA), and the ligation mixture was introduced into E. coli DH5a competent cells by electroporation [16]. Plasmid DNA was prepared by using a plasmid DNA purification kit (iNtRon, Korea). Restriction enzyme digestion and agarose gel electrophoresis were done according to the published methods [17].

\section{Overexpression of $v p r S J 4$ in E. coli BL21 (DE3)}

vprSJ4 was amplified without its own signal sequence using the following primer pairs, pETvprSJ4F (5'AGAGGATCCGATGGCTCCGGCTTCT-3', BamHI site underlined) and pETvprSJ4R (5'-AGACTCGAGCGC GAATTCGTCTTC-3', XhoI site underlined). The amplified fragment was inserted into pET26b(+) (Merck Millipore, Germany) after being digested with BamHI and XhoI. E. coli BL21 (DE3) competent cells were transformed with the ligation mixture by electroporation $(200 \Omega, 18 \mathrm{kV} / \mathrm{cm})$ [16]. E. coli cells harboring pETvprSJ4 were grown in $\mathrm{LB}(250 \mathrm{ml})$ containing kanamycin $(30 \mu \mathrm{g} / \mathrm{ml})$ until the $\mathrm{OD}_{600}$ of culture reached 0.8 . IPTG (isopropyl $\beta$-D-1-thiogalactopyranoside) was added to the final concentration of $1 \mathrm{mM}$, and the culture was incubated for $20 \mathrm{~h}$ at $30^{\circ} \mathrm{C}$. After centrifugation at $4,000 \times g$ for $20 \mathrm{~min}$ at $4^{\circ} \mathrm{C}$, the cell pellet was resuspended in $5 \mathrm{ml}$ of phosphate-buffered saline (PBS, pH 7.2). Cells were then disrupted by sonication (5 cycles of $1 \mathrm{~min}$ sonication and 2 min cooling on ice) using a sonicator (UW 2070, Germany). Disrupted cells were centrifuged at $12,000 \times g$ for $15 \mathrm{~min}$ at $4^{\circ} \mathrm{C}$. The supernatant (soluble fraction) and cell pellet (insoluble fraction) were obtained and used for experiments.

\section{In Vitro Renaturation and Purification of VprSJ4}

Insoluble fraction as described above was dissolved in $6 \mathrm{M}$ guanidine- $\mathrm{HCl}$. After standing for $4 \mathrm{~h}$ at $\mathrm{RT}$, the sample was dialyzed against an excess volume of Tris- $\mathrm{HCl}$ buffer $(2 \mathrm{M}, \mathrm{pH} 7.0)$ containing reducing agents (5 $\mathrm{mM}$ cysteine and $1 \mathrm{mM}$ cystine) for $12 \mathrm{~h}$ at $4^{\circ} \mathrm{C}$. Then, the dialysate was centrifuged for $20 \mathrm{~min}$ at $12,000 \times g$ at $4^{\circ} \mathrm{C}$ to remove precipitate. Buffer exchange of the dialysate was done using binding buffer $(20 \mathrm{mM}$ sodium phosphate, $0.5 \mathrm{M} \mathrm{NaCl}, 10 \mathrm{mM}$ imidazole, pH 7.4) and Amicon filters (MWCO 12,000, Millipore, USA). The dialyzed sample was then loaded onto a HiTrap IMAC FF Column (GE Healthcare, Sweden). VprSJ4 was eluted from the column by stepwise elution of buffer with increased imidazole concentration. The imidazole concentration was increased stepwise starting from $100 \mathrm{mM}$ to $500 \mathrm{mM}$ with $100 \mathrm{mM}$ increments. Fractions were checked by SDS-PAGE. Protein concentration was measured by Bradford method using bovine serum albumin as a standard [18].

\section{Western Blot Analysis of VprSJ4}

Eluents from the affinity column were separated by SDS-PAGE and proteins were transferred onto a PVDF membrane (Thermo Fisher, USA) by using a mini trans-blot electrophoretic transfer apparatus (BioRad). Then, membrane was incubated in blocking PBS buffer containing 3\% skim milk at RT for $2 \mathrm{~h}$ with shaking, and 
incubated overnight at $4^{\circ} \mathrm{C}$ with anti-His antibodies (1/500 dilution, monoclonal antibody, mouse IgG1, Thermo Fisher). The membrane was incubated with the secondary antibody (1/3,000 dilution, anti-Mouse IgG $(\mathrm{H}+\mathrm{L})$ conjugated with alkaline phosphatase, Bio-Rad) at $37^{\circ} \mathrm{C}$ for $1 \mathrm{~h}$ with shaking. After washing with PBST (PBS containing $0.1 \%(\mathrm{v} / \mathrm{v})$ Tween-20), alkaline phosphatase substrate (Bio-Rad) was added to develop color (RT, $5 \mathrm{~min}$ ).

\section{Properties of Recombinant VprSJ4}

The effect of $\mathrm{pH}$ on the fibrinolytic activity of VprSJ4 was examined by using different buffers ( $50 \mathrm{mM}$ each): citrate- $\mathrm{NaOH}$ for $\mathrm{pH} 3-5$, sodium phosphate for $\mathrm{pH}$ 6-8, and Tris-HCl for $\mathrm{pH}$ 9-11. VprSJ4 (1 $\mu \mathrm{g})$ was resuspended in each buffer and incubated for $1 \mathrm{~h}$ at $40^{\circ} \mathrm{C}$ and the fibrinolytic activities were measured by the fibrin plate method [19]. For testing $\mathrm{pH}$ stability, VprSJ4 in each buffer was incubated at $40^{\circ} \mathrm{C}$ and the activities were measured at 1,3 , and $6 \mathrm{~h}$. VprSJ4 in sodium phosphate buffer $(\mathrm{pH} 7)$ was incubated for $30 \mathrm{~min}$ at $37-60^{\circ} \mathrm{C}$ and the activities were measured to determine the optimum temperature. To test thermal stability, VprSJ4 in sodium phosphate buffer (pH 7) was incubated at $37-60^{\circ} \mathrm{C}$ and the activities were measured at $0.5,1,2$, and $3 \mathrm{~h}$. VprSJ 4 in sodium phosphate buffer $(\mathrm{pH} 7)$ was exposed to $5 \mathrm{mM}$ metal ion or $1 \mathrm{mM}$ inhibitor for $30 \mathrm{~min}\left(40^{\circ} \mathrm{C}\right)$. The remaining activities were then measured.

\section{Amidolytic Activity and Enzyme Kinetics}

$N$-Succinyl-ala-ala-pro-phe-p-nitroanilide (S7388, Sigma) was used as a substrate for amidolytic activity of VprSJ4. Fifty microliters of substrate ( $10 \mathrm{mM}$ in sodium phosphate buffer, $\mathrm{pH} 7.0$ ) was mixed with $10 \mu \mathrm{l}$ of VprSJ4 $(1 \mu \mathrm{g})$ and $440 \mu \mathrm{l}$ of sodium phosphate buffer. The mixture was incubated at $40^{\circ} \mathrm{C}$ for $20 \mathrm{~min}$, and $500 \mu \mathrm{l}$ of citrate$\mathrm{NaOH}$ buffer ( $\mathrm{pH}$ 3.0) was added and put on ice immediately. The mixture was centrifuged at $12,000 \times g$ for $5 \mathrm{~min}$ and the absorbance of the supernatant was measured at $410 \mathrm{~nm}$. The degree of hydrolysis was calculated from the absorbance value and the molar extinction coefficient value of $p$-nitroanilide $\left(8,800 \mathrm{M}^{-1} \mathrm{~cm}^{-1}\right)$ [19]. Kinetic parameters of VprSJ4 were determined by measuring the release of $p$-nitroaniline from $\mathrm{N}$-succinyl-ala-ala-prophe-p-nitroanilide in sodium phosphate buffer $(100 \mathrm{mM}, \mathrm{pH} 7.0)$ containing $4 \%(\mathrm{v} / \mathrm{v}) \mathrm{DMSO}$ at $37^{\circ} \mathrm{C}[19]$. Vpr eluted at a concentration of $200 \mathrm{mM}$ imidazole was further concentrated by using an ultra centrifugal filter (Amicon, USA, MWCO, $50 \mathrm{~K}$ ). The concentrated Vpr was used for kinetic measurements. $V_{\max }$ and $K_{\mathrm{m}}$ were determined from measurements at different substrate concentrations ranging from 0.03 to $0.8 \mathrm{mM}$. $V_{\max }$ was converted to $\mathrm{k}_{\text {cat }}$ from the relationship $K_{\text {cat }}=V_{\text {max }} /[$ enzyme].

\section{Coexpression of aprESJ4 and vprSJ4 in B. subtilis WB600}

aprESJ4 and $v$ prSJ4 were amplified by PCR. Primers used were as follows: aprE-F (5'-ATCTAGACAAGAGAG CGATTGCGGCTGTG-3', XbaI), aprE-R, (5'-AGGATCCTTCAGAGGGAGCCA CCCGTCG-3', BamHI), vpr-F (5'-CGGATCCTACACAGGTTTATTCACTTA TAC-3 BamHI), and vpr-R (5'-GGAATTCGAAGATAAGCT CCGATCGTAT-3' EcoRI). Restriction site is underlined. PCR was done as described above. aprESJ4 (1.5 kb) and $\mathrm{v} p r S J 4(2.7 \mathrm{~kb})$ were digested separately. Then both genes were mixed and ligated with pHY300PLK cut with XbaI and EcoRI. The ligation mixture was introduced into B. subtilis WB600 competent cells by electroporation. B. subtilis WB600 was kindly provided by Dr. S. L. Wong (University of Calgary, Canada) [20]. Gene Pulser II (BioRad) was used and the conditions were $200 \Omega, 25 \mu \mathrm{F}$ and $2.1 \mathrm{kV} / \mathrm{cm}$. After pulse, $1 \mathrm{ml}$ of LB broth with $0.5 \mathrm{M}$ sorbitol and $0.38 \mathrm{M}$ mannitol was added and the cells were recovered for $3 \mathrm{~h}$ at $37^{\circ} \mathrm{C}$ with shaking.

B. subtilis WB600 TFs were grown in LB containing tetracycline $(10 \mu \mathrm{g} / \mathrm{ml})$ for $96 \mathrm{~h}$. Aliquots of culture were taken at $12 \mathrm{~h}$ intervals, and culture supernatant was obtained. Fibrinolytic activities, SDS-PAGE, and fibrin zymography were done for the culture supernatants as described above.

\section{Results and Discussions}

Fibrinolytic Enzymes from $B$. subtilis SJ4

B. subtilis SJ4 was grown in LB for $96 \mathrm{~h}$. Culture supernatants obtained at $12 \mathrm{~h}$ intervals were analyzed by SDSPAGE and fibrin zymography (Fig. 1). As reported previously, $28 \mathrm{kDa}$ protein is the mature AprESJ4, and the major fibrinolytic enzyme (Fig. 1B) [12]. The band intensity of AprESJ4 became stronger at $48 \mathrm{~h}$ and thereafter. Other proteins with fibrinolytic activity were observed on the zymogram, and they were $68,50,36,23$, and $20 \mathrm{kDa}$ in size (Fig. 1B). These fibrinolytic proteins were also found at the corresponding positions on SDS-PAGE gel (Fig. 1A). The $68 \mathrm{kDa}$ band in the zymogram was suspected to be Vpr considering the known size of the mature Vpr [2]. We decided to clone vpr gene from B. subtilis SJ4, and study the properties of Vpr. Moreover, B. subtilis SJ4 possesses significant salt tolerance, and can grow well in the presence of $\mathrm{NaCl}$ up to $15 \%$ (w/v) [12], which is a big advantage if B. subtilis SJ4 is used as a starter for jeotgal and other fermented foods with high salt content. Considering its high salt tolerance, GRAS status, and strong fibrinolytic activity, we believe that studies on other fibrinolytic enzymes from $B$. subtilis $\mathrm{SJ} 4$ are necessary.

\section{Analysis of Vpr \\ A $2.5 \mathrm{~kb}$ PCR fragment was ligated into pGEM-T easy vector. The recombinant plasmid, pGEMSJ4 (5.5 kb, Ap $)^{\mathrm{r}}$, was sequenced (2,506 nucleotides, MN055601), and BLAST analysis located a $v$ pr gene. The ORF was 2,433 bp in size (Fig. S1), encoding a protein of 810 amino acids. The molecular weight and pI were $85,955.70 \mathrm{Da}$ and 6.14, respectively. The first 28 amino acids seemed to be a signal peptide as judged by the signalP 4.1 server (Technical University of Denmark). The next 132 amino acids were suspected to be a prosequence when compared with other Vpr enzymes [21], and the first amino acid of the mature enzyme was methionine at $161^{\text {st }}$. The $\mathrm{pI}$ and molecular mass of the mature enzyme were 5.25 and $68,467.35 \mathrm{Da}$, respectively. Although a $68 \mathrm{kDa}$ band was not located on}


A B

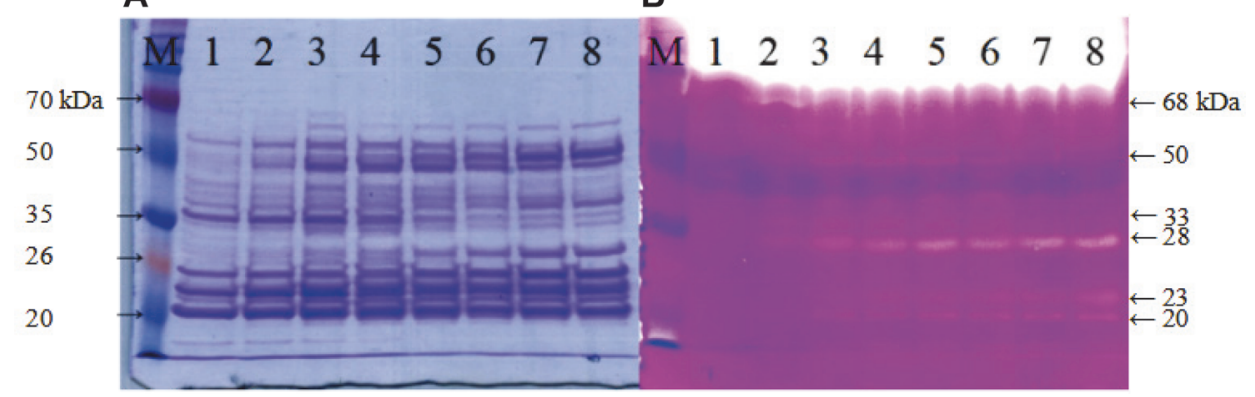

Fig. 1. Coomassie Blue-stained gel (A) and fibrin zymogram (B) of supernatant from B. subtilis SJ4. M, Dokdo-marker (EBM-1032, Elpis-Biotech., Korea). B. subtilis SJ 4 was grown in LB broth for $96 \mathrm{~h}$ at $37^{\circ} \mathrm{C} .1,12 \mathrm{~h} ; 2,24 \mathrm{~h} ; 3,36 \mathrm{~h}$; 4, $48 \mathrm{~h} ; 5.60 \mathrm{~h} ; 6,72 \mathrm{~h} ; 7,84 \mathrm{~h} ; 8,96 \mathrm{~h} .10 \mu \mathrm{g}$ protein concentrated by TCA precipitation was used for SDS-PAGE, and $1 \mu \mathrm{g}$ protein without TCA precipitation was loaded for fibrin zymography. $10 \%$ acrylamide gels were used with $5 \%$ stacking gels.

SDS-acrylamide gel (Fig. 1A), a strong fibrinolytic zone was observed at $68 \mathrm{kDa}$ position on the fibrin zymogram just below the top strong hydrolytic zone (Fig. 1B). When the amino acid sequence of VprSJ4 was compared with those from other Vpr enzymes, high similarity was observed: 98.15\% (638/650) with Vpr from B. subtilis GP279 (M76590) [21], and 98\% (637/650) with Vpr from B. subtilis KCTC3014 (AY973268) [22]. Vpr from B. subtilis GP279 showed 99.5\% identity with that from B. subtilis KCTC 3014, excepting a difference of 3 amino acids (69, $\left.110.401^{\text {th }}\right)$. However, VprSJ4 differed from the Vpr from B. subtilis GP279 and B. subtilis KCTC3014 by 12 and 13 amino acids, respectively (Fig. 2). Unlike 2 other Vprs, VprSJ4 has an additional 4 amino acids (DEFA) at the C-
S.J4
MDDSAPYIGA NDAWDLGYTG KGIKVAIIDT GVEYNHPDLK KNFGQYKGHD FVDNDYDPKE TPTGDPRGGA
GP279 MDDSAPYIGA NDAWDLGYTG KGIKVAIIDT GVEYNHPDLK KNFGQYKGYD FVDNDYDPKE TPTGDPRGEA
KCTC 3014 MDDSAPYIGA NDAWDLGYTG KGIKVAIIDT GVEYNHPDLK KNFGQYKGYD FVDNDYDPKE TPTGDPRGGA
$\begin{array}{ll}\text { SU4 } & \text { TDHGTHVAGT VAANGT IKGV APDATLLAYR VLGPGGSGT ENV I AGVERA VQDGADVMNL SLGNSLNNPD } \\ \text { GP279 } & \text { TDHGTHVAGT VAANGT IKGV APDATLLAYR VLGPGGSGT ENV IAGVERA VQDGADVMNL SLGNSLNNPD } \\ \text { KCTC } 3014 & \text { TDHGTHVAGT VAANGT IKGV APDATLLAYR VLGPGSGTS ENV I AGVERA VQDGADVMNL SLGNSLNNPD }\end{array}$
SJ4 WATSTALDWA MSEGVVAVTS NGNSGPNGWT VGSPGTSREA ISVGATQLPL NEYAVKFGSY SSAKVMGYNK 210
GP279 WATSTALDWA MSEGVVAVTS NGNSGPNGWT VGSPGTSREA ISVGATQLPL NEYAVTFGSY SSAKVMGYNK
KCTC 3014 WATSTALDWA MSEGVVAVTS NGNSGPNGWT VGSPGTSREA ISVGATQLPL NEYAVTFGSY SSAKVMGYNK
SJ4 EDDVKALNNK EVELVEAGIG EAKDFEGKDL TGKVAVVKRG SIAFVDKADN AKKAGAIGMV VYNNLSGEIE 280
GP279 EDDVKALNNK EVELVEAGIG EAKDFEGKDL TGKVAVVKRG SIAFVDKADN AKKAGAIGMV VYNNLSGEIE
KCTC 3014 EDDVKALNNK EVELVEAGIG EAKDFEGKDL TGKVAVVKRG SIAFVDKADN AKKAGAIGMV VYNNLSGEIE SJ4 ANVPGMSVPT IKLSLEDGEK LVSALKAGET KTTFKLTVSK ALGEQVADFS SRGPVMDTWM IKPDISAPGA 350
GP279 ANVPGMSVPT IKLSLEDGEK LVSALKAGET KTTFKLTVSK ALGEQVADFS SRGPVMDTWM IKPDISAPGV
KCTC 3014 ANVPGMSVPT IKLSLEDGEK LVSALKAGET KTTFKLTVSK ALGEQVADFS SRGPVMDTWM IKPDISAPGV
SJ4 NIVSTIPTHD PGHPYGYGSK QGTSMASPHI AGAVAVIKQA KPKWSVEQIK AAIMNTAVTL KDGDGEVYPH
GP279 NIVSTIPTHD PDHPYGYGSK QGTSMASPHI AGAVAVIKQA KPKWSVEQIK AAIMNTAVTL KDSDGEVYPH
KCTC 3014 NIVSTIPTHD PDHPYGYGSK QGTSMASPHI AGAVAVIKQA KPKWSVEQIK TAIMNTAVTL KDSDGEVYPH
SJ4 NAQGAGSARI MNAIKADSLV SPGSYSYGTF LKENGNETKN ETFTIENQSS IRKSYTLEYS FNGSGISTSG 490
GP279 NAQGAGSARI MNAIKADSLV SPGSYSYGTF LKENGNETKN ETFTIENQSS IRKSYTLEYS FNGSGISTSG
KCTC 3014 NAQGAGSARI MNAIKADSLV SPGSYSYGTF LKENGNETKN ETFTIENQSS IRKSYTLEYS FNGSGISTSG
SJ4 TSRVVIPAHQ TGKATAKVKV NTKKTKAGTY EGTVIVREGG KTVAKVPTLL IVKEPDYPRV TSVSVSEGSV 560
GP279 TSRVVIPAHQ TGKATAKVKV NTKKTKAGTY EGTVIVREGG KTVAKVPTLL IVKEPDYPRV TSVSVSEGSV
KCTC 3014 TSRVVIPAHQ TGKATAKVKV NTKKTKAGTY EGTVIVREGG KTVAKVPTLL IVKEPDYPRV TSVSVSEGSV
S.J4
SJ4 QGTYQIETYL PAGSEELAFL VYDSNLDFAG QAGIYKNODK GYQYFDWDGT INGGTKLPAG EYYLLAYAAN
KCTC 3014 QGTYQIETYL PAGAEELAFL VYDSNLDFAG QAGIYKNODK GYYYFDWDGT INGGTKLPAG EYYLLAYAAN
* * * * ****
GP279 $\quad$ KGKSSQVLTE EPFTVE--
KCTC 3014 KGKSSQVLTE EPFTVE--

\section{0}

\section{0}

\section{0}

\section{0} 560

Fig. 2. Alignment of amino acid sequence of mature VprSJ4 with homologous enzymes, Vpr from B. subtilis GP279 (M76590), and Vpr from B. subtilis KCTC 3014 (AY973268). Amino acids different from each other are marked with an asterisk above. 


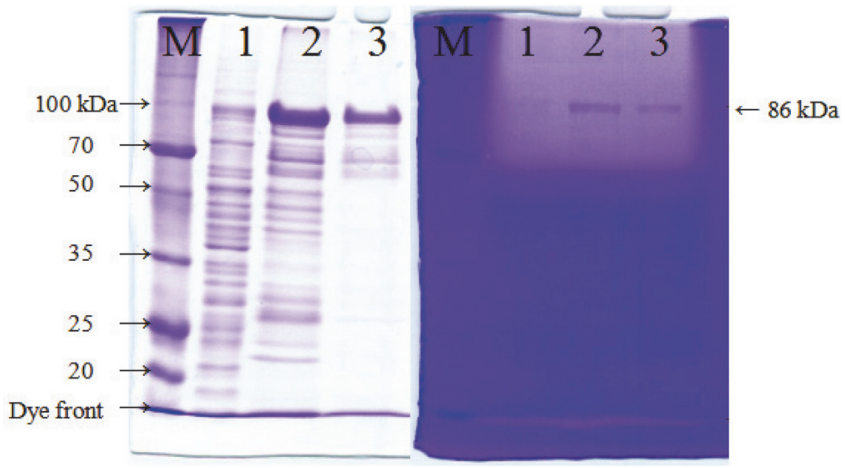

Fig. 3. Purification of recombinant VprSJ4 from insoluble fraction. M, Dokdo-marker (EBM-1034, Elpisbio, Korea); 1, insoluble fraction; 2 , eluent at $100 \mathrm{mM}$ imidazole concentration; 3, eluent at $200 \mathrm{mM}$ imidazole concentration.

terminus (Fig. 2), making VprSJ4 slightly larger than other Vprs. It will be interesting to study the effect of these 4 extra amino acids on the enzyme properties, including the $\mathrm{C}$-terminus cleavage.

\section{Overexpression of $v$ prSJ 4 in E. coli and Purification of Recombinant VprSJ4}

VprSJ4 was overproduced in E. coli as a fusion protein containing 6 additional His (6 x His-tag) at the Cterminus, which facilitated the purification of recombinant VprSJ4 by affinity chromatography. When both soluble and insoluble fractions were analyzed by SDS-PAGE, a thick $86 \mathrm{kDa}$ band was observed mainly from insoluble fraction (Fig. S2), indicating that VprSJ4 was not processed properly and aggregated as an inclusion body in E. coli [15]. The size matched that of preproenzyme ( $86 \mathrm{kDa})$.

VprSJ4 from insoluble fraction was purified by using a HiTrap IMAC FF Column after in vitro renaturation steps. PreproVprSJ4 was eluted from the column at $100 \mathrm{mM}$ imidazole concentration together with other minor proteins. Additional preproVprSJ4 was eluted with a few other proteins at $200 \mathrm{mM}$ imidazole concentration. PreproVprSJ4 was no longer eluted at $300 \mathrm{mM}$ and higher imidazole concentrations (results not shown). Insoluble fraction and eluents at 100 and $200 \mathrm{mM}$ imidazole concentration had fibrin degrading activities, shown as a big halo at the top of the fibrin gel (Fig. 3B). The results indicated that preproVprSJ4 was processed and some active forms were regenerated through in vitro renaturation processes. The active $68 \mathrm{kDa}$ band was not located on the fibrin gel because the location was masked by the big halo at the top. However, a band of $68 \mathrm{kDa}$ in size was observed in an SDS-gel (lanes 2 and 3, Fig. 3). Although other fibrinolytic bands were not located on the fibrin zymogram, it was still possible that smaller proteins were generated from preproVprSJ4 during in vitro renaturation steps.

\section{Western Blot Analysis of VprSJ4}

Small fragments were detected by SDS-PAGE and western blot (Fig. 4), indicating autoprocessing of preproVprSJ4. Antibody against His-tag detected an $86 \mathrm{kDa}$ band together with proteins of $68 \mathrm{kDa}$ and smaller $(55,50,48,32,28,26,22$, and $20 \mathrm{kDa})(\mathrm{Fig}$. 4B). These small proteins might be degradation products of the $68 \mathrm{kDa}$
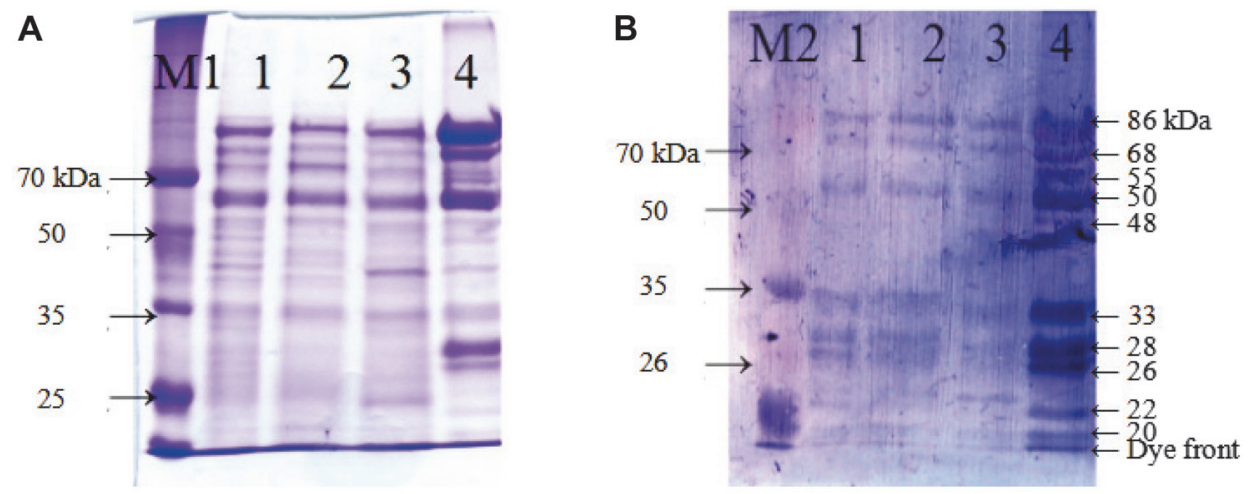

Fig. 4. SDS-PAGE and western blot of VprSJ4 purified from insoluble fraction. (A) SDS-PAGE of purified VprSJ4 using a HiTrap IMAC FF column. (B) Western blot analysis of VprSJ4. M1, Dokdo-marker (EBM-1034); M2, Dokdo-marker (prestained, EBM-1032); 1, insoluble fraction from E. coli BL21(DE3) [pETvprSJ4] grown for $20 \mathrm{~h}$ after IPTG induction; 2, flow through; 3, eluent from column flushed with wash buffer ( $20 \mathrm{mM}$ sodium phosphate, $\mathrm{pH} 7.4,20 \mathrm{mM}$ imidazole, and $0.5 \mathrm{M}$ $\mathrm{NaCl}$ ); 4, eluent from column flushed with elution buffer with $100 \mathrm{mM}$ imidazole concentration. After color development of the PVDF membrane with alkaline phosphatase substrate solution, the bands were purple. The color tone of the scan result was adjusted to blue to enhance the contrast. 
mature Vpr by N-terminal processing since the His-tag was attached to C-terminus of Vpr. In a previous study on Vpr from B. subtilis 168, small proteins detected by His-tag antibody were identified as N-terminus deletion derivatives of Vpr by MALDI-TOP mass spectrometry [15]. In another study, Vpr was purified from culture supernatant by gel filteration and eluted from column in void volume, forming a complex with other proteins [21]. When the Vpr complex was subjected to SDS-PAGE, 38, 28.5, and $27 \mathrm{kDa}$ bands were separated. When Nterminal amino acids were determined, the $28 \mathrm{kD}$ a protein had the same $\mathrm{N}$-terminal amino acid sequence with the mature $68 \mathrm{kDa} \mathrm{Vpr}$, indicating C-terminal processing of Vpr. For $27 \mathrm{kDa}$ protein, the first 9 amino acids of mature enzyme were missing [21]. These reports indicated that both $\mathrm{N}$-terminal and C-terminal processing of Vpr occur in vivo.

A few bands were observed between 20 and $32 \mathrm{kDa}$ (lane 4, Fig. 4B), and 26 and $28 \mathrm{kDa}$ bands were likely processed derivatives of Vpr. Further study will be necessary to confirm the exact processing of VprSJ4 in vivo.

\section{Properties of Recombinant VprSJ4}

VprSJ4 eluted at $200 \mathrm{mM}$ imidazole concentration was centrifuged using an Ultra-15 Centrifugal Filter (Amicon, $3 \mathrm{kDa}$, MWCO) to remove imidazole. Desalted VprSJ4 was used for studies on its properties. VprSJ4 maintained higher activity at $\mathrm{pH} 6-10$, and the highest activity was observed at $\mathrm{pH} 7.0$ (Fig. 5A), which was lower ( $\mathrm{pH}$ 9.0) than that of partially purified Vpr from B. subtilis KCTC3014 [22]. The difference in optimum $\mathrm{pH}$ might be due to the difference in amino acid sequence or additional 4 amino acids at the $\mathrm{C}$-terminus. Relative activity of $87.2,91.4,81.7$, and $77.7 \%$ were observed at $\mathrm{pH} 6,8,9$, and 10 , respectively. The enzyme had no activity at $\mathrm{pH} 4$ and below. The activity declined rapidly at $\mathrm{pH}$ above 10; it continued to decrease over $6 \mathrm{~h}$ incubation at all $\mathrm{pHs}$, and rapid inactivation occurred at $\mathrm{pH} 5$ and below (Fig. 5B).
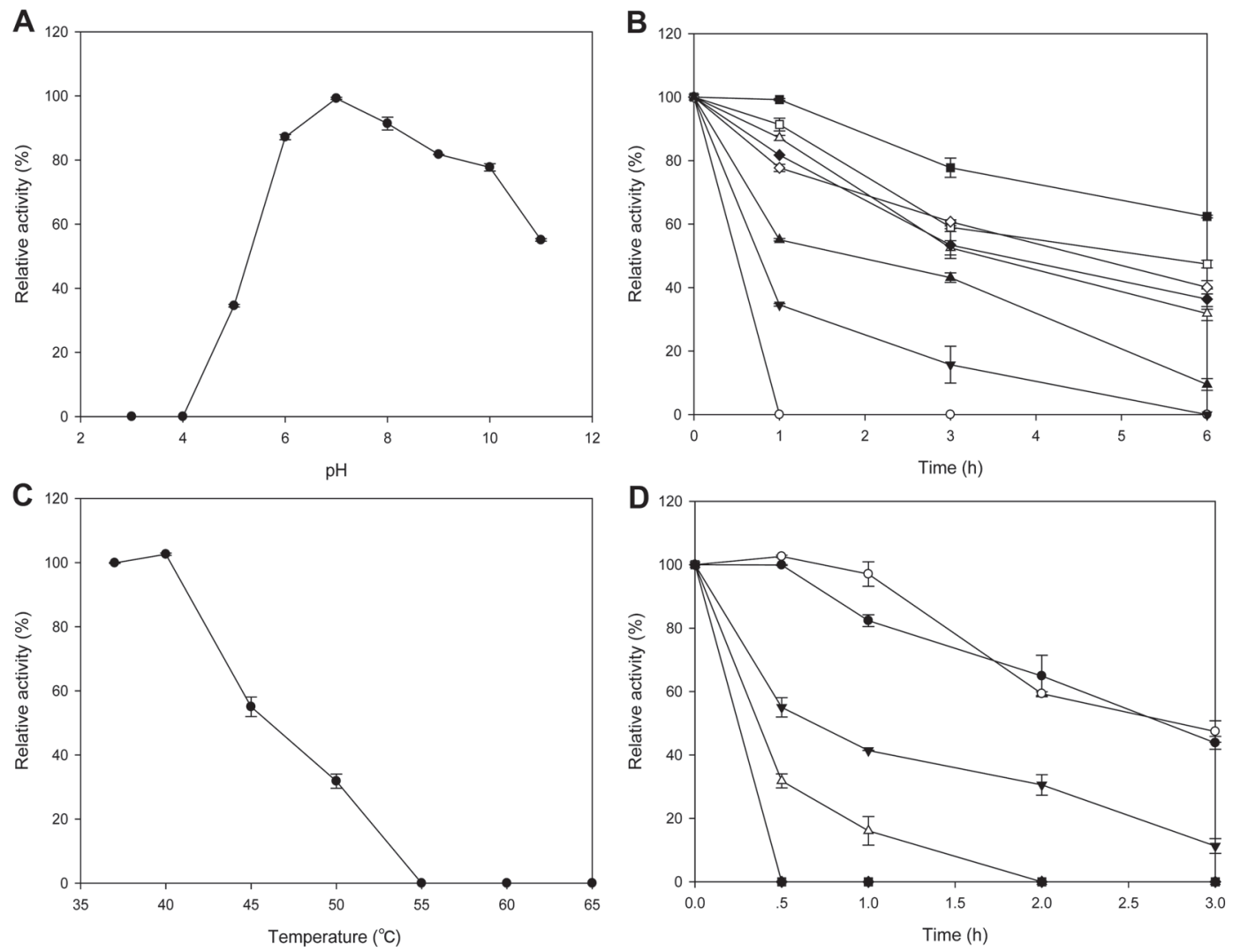

Fig. 5. Properties of Recombinant VprSJ4. VprSJ4 eluted at $200 \mathrm{mM}$ imidazole concentration was centrifuged using an Ultra-15 Centrifugal Filter (Amicon, $3 \mathrm{kDa}, \mathrm{MWCO}$ ) to remove imidazole. Desalted VprSJ4 was used for studies on its properties. pH 7.0 was the optimum pH for the activity and VprSJ4 maintained higher activity at pH 6-10 (Fig. 5A). The optimum pH was 9.0 for partially purified Vpr from B. subtilis KCTC3014 [22]. The difference in optimum pH might be due to the different amino acid sequences or additional 4 amino acids of VprSJ4 at the C-terminus. VprSJ4 showed relative activity of $87.2,91.4,81.7$, and $77.7 \%$ at $\mathrm{pH} 6,8,9$, and 10, respectively. VprSJ4 showed no activity at pH 4 and below. The activity declined rapidly at $\mathrm{pH}$ above 10 . During $6 \mathrm{~h}$ incubation, the activity decreased continuously at all $\mathrm{pHs}$, and rapid inactivation occurred at pH 5 and below (Fig. 5B). The optimum temperature was $40^{\circ} \mathrm{C}$ at pH 7 (Fig. 5C), which was the same temperature reported for partially purified Vpr from B. subtilis KCTC3014 [22]. When the temperature was increased to $55^{\circ} \mathrm{C}$ and above, no activity was detected after $30 \mathrm{~min}$ incubation. During $3 \mathrm{~h}$ incubation, the activity decreased continuously, and especially decreased rapidly at $50^{\circ} \mathrm{C}$ and above. The results showed that VprSJ4 has moderate stabilities against $\mathrm{pH}$ and temperature. 
Table 1. Effects of metal ions and inhibitors on the activity of VprSJ4.

\begin{tabular}{cccc}
\hline Metal ions $(5 \mathrm{mM})$ & Relative activity $(\%)$ & Inhibitors $(1 \mathrm{mM})$ & Relative activity $(\%)$ \\
\hline None & 100 & PMSF & $0.00 \pm 0.00$ \\
$\mathrm{Mn}^{2+}$ & $102.06 \pm 0.56$ & EDTA & $15.13 \pm 0.92$ \\
$\mathrm{Mg}^{2+}$ & $105.60 \pm 0.59$ & EGTA & $22.99 \pm 2.60$ \\
$\mathrm{Ca}^{2+}$ & $108.74 \pm 0.59$ & SDS & $81.38 \pm 2.41$ \\
$\mathrm{~K}^{+}$ & $100.93 \pm 0.97$ & \\
$\mathrm{Zn}^{2+}$ & $86.72 \pm 1.05$ & \\
$\mathrm{Fe}^{3+}$ & $92.21 \pm 0.06$ & \\
$\mathrm{Na}^{+}$ & $99.61 \pm 0.19$ & & \\
$\mathrm{Co}^{2+}$ & $86.72 \pm 1.05$ & & \\
\hline
\end{tabular}

The counter ion for the tested metals was chloride.

All values are the mean $\pm \mathrm{SD}(n=3)$.

The optimum temperature was $40^{\circ} \mathrm{C}$ at $\mathrm{pH} 7$ (Fig. 5C), which was the same as that of partially purified Vpr from B. subtilis KCTC3014 [22]. When we increased the temperature to $55^{\circ} \mathrm{C}$ and above, no activity remained after $30 \mathrm{~min}$ incubation. The activity decreased continuously over $3 \mathrm{~h}$ incubation, and also decreased rapidly at $50^{\circ} \mathrm{C}$ and above. The results showed that VprSJ4 has moderate stabilities against $\mathrm{pH}$ and temperature.

The effects of metals and inhibitors on the activity of VprSJ4 are presented in Table 1. Ca ${ }^{2+}$ enhanced the fibrinolytic activity by $8.74 \%$ followed by $\mathrm{Mg}^{2+}(5.60 \%)$ and $\mathrm{Mn}^{2+}(2.06 \%)$. The activity was inhibited by $\mathrm{Co}^{2+}$ (13.28\% inhibition) and $\mathrm{Zn}^{2+}$ (13.28\% inhibition). The fibrinolytic activity was completely inhibited by PMSF, and most of the activity was inhibited by EDTA ( $84.87 \%$ inhibition), and EGTA (77.01\% inhibition), but was not affected by SDS. The results showed that VprSJ4 is a serine protease and also a metal protease.

\section{Kinetics and Amidolytic Activity Measurements}

The $K_{\mathrm{m}}$ and $V_{\max }$ of recombinant VprSJ4 were $0.19 \mathrm{mM}$ and $29.76 \mu \mathrm{M} / \mathrm{min}$, respectively, and $K_{\text {cat }}$ was $33.96 \mathrm{~S}^{-1}$. $K_{\mathrm{cat}} / K_{\mathrm{m}}$ of recombinant VprSJ4 was $1.79 \times 10^{5} \mathrm{~S}^{-1} \mathrm{M}^{-1}$. As far as we know, this is the first report on the kinetic parameters of $\mathrm{Vpr}$ from Bacillus species. The values were compared with those of other fibrinolytic enzymes from Bacillus species where kinetic parameters were reported by using the same substrate, $N$-succinyl-ala-ala-pro-phep-nitroanilide. B. pumilus BS15 was isolated from jeotgal made with oyster and its main fibrinolytic enzyme, AprEBS15, showed $K_{\mathrm{m}}$ and $V_{\max }$ of $0.26 \mathrm{mM}$ and $21.88 \mu \mathrm{M} / \mathrm{min}$, respectively [23]. The $K_{\text {cat }}$ was $10.02 \mathrm{~S}^{-1}$, and $K_{\text {cat }} /$ $K_{\mathrm{m}}$ was $3.85 \times 10^{4} \mathrm{~S}^{-1} \mathrm{M}^{-1}$. B. subtilis $\mathrm{HK} 176$ was isolated from cheonggukjang and its main fibrinolytic enzyme gene, $a p r E 176$, was cloned [19]. The $K_{\mathrm{m}}, K_{\mathrm{cat}}$, and $K_{\mathrm{cat}} / K_{\mathrm{m}}$ of AprE176 were $0.453 \mathrm{mM}, 122.851 \mathrm{~S}^{-1}$, and $2.71 \times 10^{5}$ $\mathrm{S}^{-1} \mathrm{M}^{-1}$, respectively [19]. B. subtilis DC33, an isolate from the Chinese fermented food douchi (salted black soybean), secretes a $30 \mathrm{kDa}$ subtilisin-type enzyme, which showed $K_{\mathrm{m}} K_{\mathrm{cat}}$, and $K_{\mathrm{cat}} / K_{\mathrm{m}}$ of $0.21 \mathrm{mM}, 37.04 \mathrm{~S}^{-1}$, and $1.76 \times 10^{5} \mathrm{~S}^{-1} \mathrm{M}^{-1}$, respectively [24]. B. subtilis IMR-NK1, a strain used for natto production, produces a $31.5 \mathrm{kDa}$ fibrinolytic enzyme, and the enzyme showed $K_{\mathrm{m}}, K_{\mathrm{cat}}$, and $K_{\mathrm{cat}} / K_{\mathrm{m}}$ of $0.34 \mathrm{mM}, 21.08 \mathrm{~S}^{-1}$, and $6.2 \times 10^{4} \mathrm{~S}^{-1} \mathrm{M}^{-1}$, respectively [25]. Another fibrinolytic enzyme from a B. subtilis strain used for red bean natto production showed $K_{\mathrm{m}}, K_{\text {cat }}$, and $K_{\text {cat }} / K_{\mathrm{m}}$ of $0.59 \mathrm{mM}, 39.6 \mathrm{~S}^{-1}$, and $6.7 \times 10^{4} \mathrm{~S}^{-1} \mathrm{M}^{-1}$, respectively [26]. Bacillus sp. nov. SK006 was isolated from fermented shrimp paste and a fibrinolytic enzyme, $43-46 \mathrm{kDa}$ in size, was purified, and showed $K_{\mathrm{m}}, K_{\text {cat }}$, and $K_{\text {cat }} / K_{\mathrm{m}}$ of $0.45 \mathrm{mM}, 28.75 \mathrm{~S}^{-1}$, and $6.4 \times 10^{4} \mathrm{~S}^{-1} \mathrm{M}^{-1}$, respectively [27]. VprSJ4 has a lower $K_{\mathrm{m}}$ value than other fibrinolytic enzymes, mainly AprE type, indicating higher affinity for the substrate. VprSJ4 shows similar or slightly higher catalytic efficiency $\left(K_{\text {cat }} / K_{\mathrm{m}}\right.$ value) than other enzymes except AprEHK176. AprEHK176 has slightly higher efficiency than VprSJ4.

A

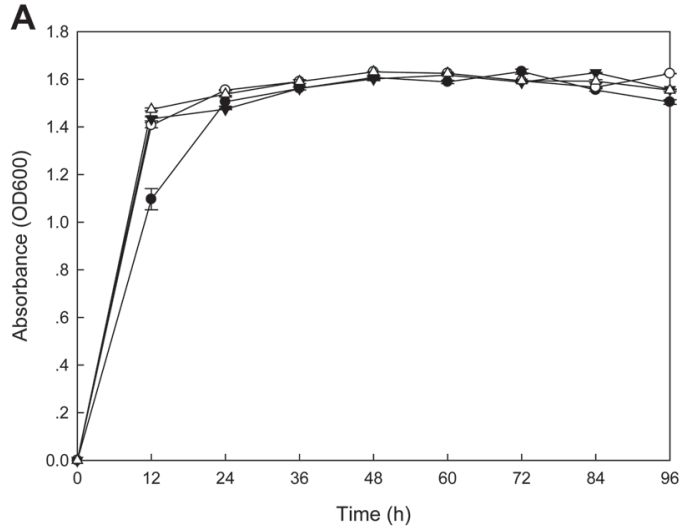

B

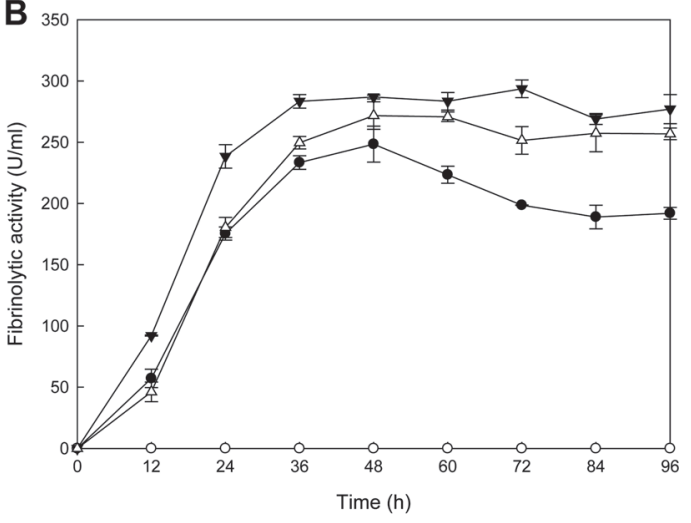

Fig. 6. Growth (A) and fibrinolytic activities (B) of B. subtilis WB600 strains. - - B. subtilis SJ4; - $\bigcirc$-, B. subtilis WB600 [pHY300PLK]; - $\mathbf{\nabla}$-, B. subtilis WB600 [pHYavSJ4]; - $\triangle$-, B. subtilis WB600 [pHYaprESJ4]. 


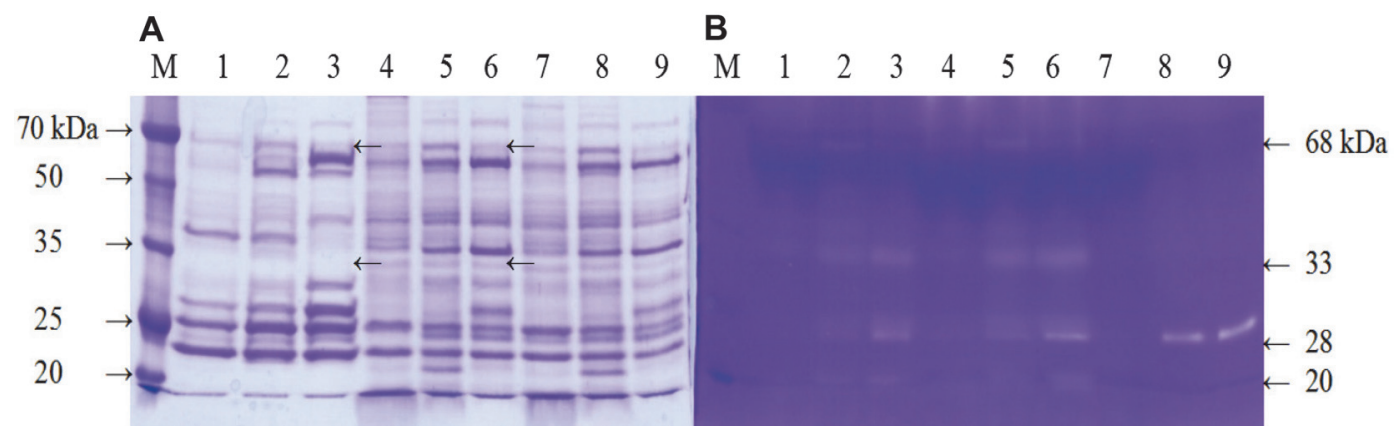

Fig. 7. Coomassie Blue-stained gel (A) and fibrin zymogram (B) of culture supernatant from B. subtilis WB600 strains. M, Dokdo-marker (EBM-1034); lanes 1-3, B. subtilis SJ4 culture supernatant at $24 \mathrm{~h}$ (1), $48 \mathrm{~h}$ (2), and $96 \mathrm{~h}$ (3); lanes 4-6, B. subtilis WB600 [pHYavSJ4] culture supernatant at $24 \mathrm{~h} \mathrm{(4),} 48 \mathrm{~h} \mathrm{(5),} \mathrm{and} 96 \mathrm{~h}$ (6); lanes 7-9, B. subtilis WB600 [pHYaprESJ4] culture supernatant at $24 \mathrm{~h}(7), 48 \mathrm{~h}(8)$, and $96 \mathrm{~h}(9)$.

\section{Coexpression of aprESJ4 and vprSJ4 in B. subtilis WB600}

B. subtilis WB600 harboring pHYavSJ4 (pHY300PLK containing aprESJ4 and vprSJ4) showed the same growth curve as B. subtilis WB600 [pHY300PLK] (control) and B. subtilis SJ4 (Fig. 6A). B. subtilis WB600 [pHYavSJ4] showed the highest fibrinolytic activity $(293.6 \mathrm{U} / \mathrm{ml})$ at $72 \mathrm{~h}$ whereas control did not show any significant activity (Fig. 6B). B. subtilis SJ4 showed the highest fibrinolytic activity $(248.4 \mathrm{U} / \mathrm{ml})$ at $48 \mathrm{~h}$ and B. subtilis WB600 [pHYaprE34] showed the highest activity $(271.8 \mathrm{U} / \mathrm{ml})$ at 48 h. B. subtilis WB600 [pHYaprESJ4] showed higher fibrinolytic activity than B. subtilis SJ4, but lower than B. subtilis WB600 [pHYavSJ4]. At $72 \mathrm{~h}$, the activity of B. subtilis WB600 [pHYavSJ4] was 1.48 fold and 1.17 fold higher than that of B. subtilis SJ4 and B. subtilis WB600 [pHYaprESJ4], respectively. The result indicated that coexpression of vprSJ4 and aprESJ4 caused additional increase in the fibrinolytic activity of $B$. subtilis WB600. The activity could be increased further if efforts to optimize gene expression of aprESJ4 and vprSJ4 are made in the future, along with the use of other vectors and promoter changes.

SDS-PAGE of culture supernatant of B. subtilis WB600 [pHYavSJ4] showed that sizes of 68, 60, 45, 33, 28, 25 , and $22 \mathrm{kDa}$ were observed in addition to other minor bands on a Coomassie Blue-stained gel (Fig. 7A). The zymogram (Fig. 7B) of the recombinant strain (lanes 4-6) clearly showed the mature VprSJ4 band (68 kDa) and the mature AprESJ4 band ( $28 \mathrm{kDa}$ ). The control (lanes 7-9) showed only the mature AprESJ4 band. The 33k Da band observed on the zymogram (lanes 4-6) was a degradation product from VprSJ4. The overall profiles of the zymogram are the same for B. subtilis SJ4 and B. subtilis WB600 [pHYavSJ4]. The zymogram results indicated that AprESJ4 as well as VprSJ4 are largely responsible for the fibrinolytic activity of B. subtilis SJ4, and VprSJ4 seemed to be autoprocessed in a heterologous host, just as in the original host. B. subtilis WB600 seemed to be deficient in Vpr activity since 68 and $33 \mathrm{kDa}$ bands were not observed in cells carrying only aprESJ4 (Fig. 7B, lanes 7-9).

B. subtilis SJ4 has good potential for use as a starter for fermented foods, especially foods containing less than $15 \%$ salt $(\mathrm{w} / \mathrm{v})$, because of its GRAS status, strong fibrinolytic activity, and significant salt tolerance. The fibrinolytic activity of B. subtilis SJ 4 can enhance the functionality of fermented foods where the strain is used as a starter. Fibrinolytic enzymes from Bacillus species have potential to be developed as an alternative to t-PA, urokinase, or streptokinase, which are prescribed for preventing or treating cardiovascular diseases by dissolving fibrin clots in blood vessels $[4,6]$. Unlike the case of AprE, not many studies have been done on Vpr, neither on its roles during growth at later exponential phase and stationary phase, nor its contribution to the overall fibrinolytic capacity of a Bacillus strain. Further studies on Vpr and other minor proteases will help us understand the fibrinolytic capacity of Bacillus species and find ways to utilize these fibrinolytic enzymes for medicinal uses and production of functional foods.

\section{Acknowledgments}

This work was supported by the Basic Science Research Program through the National Research Foundation of Korea (NRF) funded by the Ministry of Education (2017R1D1A1B03030037). Yao Z, Meng Y, Lee SJ, and Yoo JY were supported by the BK21 Plus Program, MOE, Republic of Korea. Le HG and Jeon HS were supported by fulltime graduate student scholarship from Gyeongsang National University.

\section{Conflicit of Interest}

The authors have no financial conflicts of interest to declare.

\section{References}

1. Kawamura F, Doi RH. 1984. Construction of a Bacillus subtilis double mutant deficient in extracellular alkaline and neutral proteases. J. Bacteriol. 160: 442-444.

2. Choi NS, Chung DM, Park CS, Ahn KH, Kim JS, Song JJ, et al. 2010. Expression and identification of a minor extracellular fibrinolytic enzyme (Vpr) from Bacillus subtilis KCTC 3014. Biotechnol. Bioprocess Eng. 15: 446-452. 
3. Veening JW, Igoshin OA, Eijlander RT, Nijland R, Hamoen LW, Kuipers OP. 2008. Transient heterogeneity in extracellular protease production by Bacillus subtilis. Mol. Syst. Biol. 4: 184

4. Chen H, McGowan EM, Ren N, Lal S, Nassif N, Shad-Kaneez F, et al. 2018. Nattokinase: a promising alternative in prevention and treatment of cardiovascular diseases. Biomark. Insights 13: 1-8.

5. Omura K, Hitosugi M, Zhu X, Ikeda M, Maeda H, Tokudome S. 2005. A newly derived protein from Bacillus subtilis natto with both antithrombotic and fibrinolytic effects. J. Pharmacol. Sci. 99: 247-251.

6. Weng Y, Yao J, Sparks S, Wang KY. 2017. Nattokinase: an oral antithrombotic agent for the prevention of cardiovascular disease. Int. J. Mol. Sci. 18: E523.

7. Lanigan-Gerdes S, Dooley AN, Faull KF, Lazazzera BA. 2007. Identification of subtilisin, Epr and Vpr as enzymes that produce CSF, an extracellular signaling peptide of Bacillus subtilis. Mol. Microbiol. 65: 1321-1333.

8. Corvey C, Stein T, Düsterhus S, Karas M, Entian KD. 2003. Activation of subtilin precursors by Bacillus subtilis extracellular serine proteases subtilisn (AprE), WprA, and Vpr. Biochem. Biophys. Res. Commun. 304: 48-54.

9. Kim W, Choi K, Kim Y, Park H, Choi J, Lee Y, et al. 1996. Purification and characterization of a fibrinolytic enzyme produced from Bacillus sp. strain CK 11-4 screened from Chungkook-jang. Appl. Environ. Microbiol. 62: 2482-2488.

10. Ahn MJ, Ku HJ, Lee SH, Lee JH. 2015. Characterization of a novel fibrinolytic enzyme, BsfA, from Bacillus subtilis ZA400 in kimchi reveals its pertinence to thrombosis treatment. J. Microbiol. Biotechnol. 25: 2090-2099.

11. Hwang KJ, Choi KH, Kim MJ, Park CS, Cha J. 2007. Purification and characterization of a new fibrinolytic enzyme of Bacillus licheniformis KJ-31, isolated from Korean traditional jeot-gal. J. Microbiol. Biotechnol. 17: 1469-1476.

12. Yao Z, Meng Y, Le HG, Kim JA, and Kim JH. 2019. Isolation of Bacillus subtilis SJ4 from saeu (shrimp) jeotgal, a Korean fermented seafood, and its fibrinolytic activity. Microbiol. Biotechnol. Lett. 47: 522-529.

13. Kwon GH, Lee HA, Park JY, Kim JS, Lim JK, Park CS, et al. 2009. Development of a RAPD-PCR method for identification of Bacillus species isolated from Cheonggukjang. Int. J. Food Microbiol. 129: 282-287.

14. Yao Z, Kim JA, Kim JH. 2019. Characterization of a fibrinolytic enzyme secreted by Bacillus velezensis BS2 isolated from sea squirt jeotgal. J. Microbiol. Biotechnol. 29: 347-356.

15. Kho CW, Park SG, Cho S, Lee DH, Myung PK, Park BC. 2005. Confirmation of Vpr as a fibrinolytic enzyme present in extracellular proteins of Bacillus subtilis. Protein Expr. Purif. 39: 1-7.

16. Dower WJ, Miller JF, Ragsdale CW. 1988. High efficiency transformation of E. coli by high voltage electroporation. Nucl. Acids Res. 16: 6127-6145

17. Sambrook J, Russell DW. 2001. Molecular cloning a laboratory manual, chapter $5.3^{\text {rd }}$ Ed. Cold Spring Harbor laboratory Press, Cold Spring harbor, New York.

18. Bradford MM. 1976. A rapid and sensitive method for the quantitation of microgram quantities of protein utilizing the principle of protein-dye binding. Anal. Biochem. 72: 248-254.

19. Jeong SJ, Heo K, Park JY, Lee KW, Park JY, Joo SH, et al. 2015. Characterization of AprE176, a fibrinolytic enzyme from Bacillus subtilis HK176. J. Microbiol. Biotechnol. 25: 89-97.

20. Wu XC, Lee W, Tran L, Wong SL. 1991. Engineering a Bacillus subtilis expression-secretion system with a strain deficient in six extracellular proteases. J. Bacteriol. 173: 4952-4958.

21. Sloma A, Rufo GA, Theriault JR KA, Dwyer M, Wilson SW, Pero J. 1991. Cloning and characterization of the gene for an additional extracellular serine protease of Bacillus subtilis. J. Bacteriol. 173: 6889-6895.

22. Choi NS, Chung DM, Ryu CH, Yoon KS, Maeng PJ, Kim SH. 2006. Identification of three extracellular proteases from Bacillus subtilis KCTC 3014. J. Microbiol. Biotechnol. 16: 457-464.

23. Yao Z, Kim JA, Kim JH. 2018. Gene cloning, expression, and properties of a fibrinolytic enzyme secreted by Bacillus pumilus BS15 isolated from gul (oyster) jeotgal. Biotechnol. Bioprocess Eng. 23: 293-301.

24. Wang CT, Ji BP, Li B, Nout R, Li PL, Ji H, et al. 2006. Purification and characterization of a fibrinolytic enzyme of Bacillus subtilis DC33, isolated from Chinese traditional Douchi. J. Ind. Microbiol. Biotechnol. 33: 750-758.

25. Chang CT, Fan MH, Kuo FC, Sung HY. 2000. Potent fibrinolytic enzyme from a mutant of Bacillus subtilis IMR-NK1. J. Agric. Food Chem. 48: 3210-3216.

26. Chang CT, Wang PM, Hung YF, Chung YC. 2012. Purification and biochemical properties of a fibrinolytic enzyme from Bacillus subtilis-fermented red bean. Food Chem. 133: 1611-1617.

27. Hua Y, Jiang B, Mine Y, Mu W. 2008. Purification and characterization of a novel fibrinolytic enzyme from Bacillus sp. nov. SK006 isolated from an Asian traditional fermented shrimp paste. J. Agric. Food Chem. 56: 1451-1457. 